\title{
CONSUMERS INTENTION TOWARDS PURCHASING IP CERTIFIED BEANS: AN ANALYSIS USING THE THEORY OF PLANNED BEHAVIOUR (TPB)
}

\begin{abstract}
The patterns of consumption of food have been rapidly changing. This change has been reflecting in the increase of safer and more sustainable food consumption. Agricultural foods that are grown in Integrated Production (IP) also match the new consumer food quality patterns. In Brazil, the supply of IP certified products is still small. The objective of the present study was to evaluate the consumer perception and intention of purchasing certified beans based on the replication of the Theory of Planned Behavior (TPB). The survey was conducted in Goiania (GO), Brazil, in 2014, when 160 consumers of common beans were interviewed in a local hypermarket. Data were analyzed based on the structural equation modeling (SEM). The results revealed characteristics of consumer behavior when faced to certified beans as a hypothetical product, since they are not yet available on the market. The results indicated that the theoretical model based on the TPB used to explain the intention behavior of purchasing certified beans resulted in reasonable fit indices, but with only some of the relations among constructs were consistent with the theory. Thus, the results showed that the proposed model was adequate for explaining the consumer behavior towards the IP certified beans purchasing. As exceptions, one can refer the constructs subjective norms and perceived behavioral control toward the intention of purchasing.
\end{abstract}

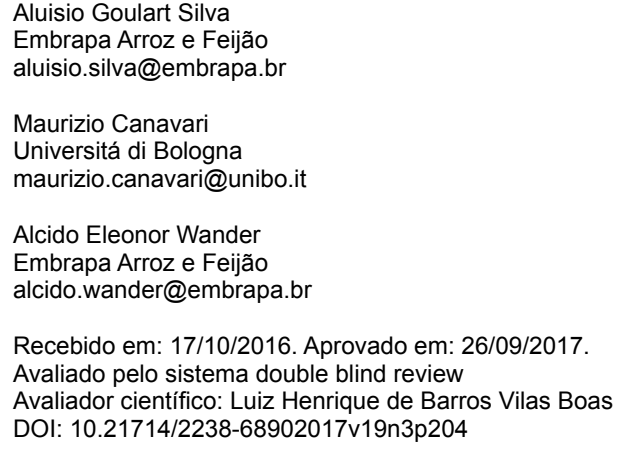

Recebido em: 17/10/2016. Aprovado em: 26/09/2017.

Avaliado pelo sistema double blind review

Avaliador científico: Luiz Henrique de Barros Vilas Boas

DOI: 10.21714/2238-68902017v19n3p204

Keywords: Consumer Behavior, Integrated Production, TPB, SEM, Common Beans.

\section{INTRODUCTION}

Comprehending the consumer decision-making process requires knowledge in different areas such as, marketing, psychology, economy and management. Several studies on consumer behavior have sought to understand the consumer logic of consumption (Magistris \& Gracia, 2008; Hoppe et al., 2012; Govindasamy \& Italia, 1999). Most of these studies show that the attention on food consumption patterns is not only related to food quality and price. Some of them have investigated consumer demand, commonly measured in terms of willingnessto-pay (WTP) for products with higher levels of quality and safety, in countries such as Australia, Canada, France, Germany, Greece, Italy, UK, USA and others. Some of them also investigated consumer WTP for various food certification and labeling schemes (Birol, Roy, Deffner, \& Karandikar, 2009). Other studies involved a wide array of food safety and quality issues such as food risks perceived by consumers, product quality and ethical and/ or environmental issues (Caswell \& Siny, 2007; Kuhar \& Juvancic, 2010; Scarpa, Spalatro, \& Canavari, 2002).

In this context, quality attributes such as foodborne pathogens, heavy metals, pesticide residues, food additives and veterinary residues became important elements in the consumer decision-making process. Another issue that became important from the consumer point of view was the production methods that focused on sustainable practices involving different concerns, such as those related to the environment and human health.

Consumers cannot directly recognize sustainability aspects because they are normally credence attributes. In this sense, consumers can never ascertain by themselves the presence of such attributes. They have to rely on the given information. Due to the credence aspect of such attributes, credence goods require standards or certifications to provide information to consumers, legitimating health and safety regulation (Moser, Raffaelli, \& McFadden, 2011). Indeed, the standards can help consumers to evaluate the 
quality of food products by increasing the transparency of the production processes and the traceability of products.

The movement toward safe foods started in Europe with the successive food crises during the last thirty years. The contaminant based 'food scares' (antibiotics, hormones and pesticides) became more concerning to consumers than hygiene standards and food poisoning. Consumers also mentioned worrying about the 'cocktail effect', which is the synergistic effect of different pesticide residues (Fontes, Giraud-Héraud, \& Pinto, 2013).

In Brazil, these concerns became more popular in the 90's with the opening of the Brazilian market worldwide. Since then, the consumption patterns of the Brazilian population have been changing due to the availability of wide options of goods and services. In this process of change, the Brazilian consumers have been valuating aspects of quality and food safety with more interest (Hoppe et al., 2012). Thus, in the long-run, food safety attributes will be in equality with all the other attributes in the sense that consumers will not take it into consideration, assuming that a food product to be available in the market should be in accordance with minimum quality patterns.

In this context, Public Authorities have established 'Minimum Quality Standards' (MQS) of safety performance for food products. The government has motivated the application of certification schemes and standards in the context of voluntary agreements, which allows the certification of the quality of agro-foods.

That said, for this study purposes, we have chosen the case of Integrated Production (IP) certification taking into account the principles of the International Organization for Biological and Integrated Control (IOBC, 2004) that cover ecological, ethical and social aspects of agriculture production as well as those related to food quality and safety.

Integrated Production (IP) has been applied in Europe since the 90's to address environmental and health concerns by reducing the net chemical pesticide inputs to agriculture and improving food quality and safety. Moreover, this production system is conducted by thinking on the preservation of natural resources and social responsibility.

Following the European experience, the Brazilian Government chose IP as a certification scheme in order to fulfill global requirements for different food products. Therefore, this study focuses on IP certification.

In Brazil, the standards of IP had its legal framework established in 2010 by the Normative Instruction $\mathrm{N}^{\circ} 27$ of 08/30/10 (BRASIL, 2010), although the first experience started with fruits ten years before. Very often, IP certification is interpreted as an improvement of the sanitary safety.
Originally, IP standards are classified as B2B (business-to-business) since they are targeted to guaranteeing quality and food safety within the supply chain. However, in this study, IP standards are also considered as B2C (business-to-consumer) since the Brazilian government focus is also on the final consumer. One of the objectives of IP certification in Brazil is to improve food quality and safety by guaranteeing compliance with minimum standards of production on the domestic consumer side (BRASIL, 2015).

The IP label has been used to communicate consumers about the intrinsic quality attributes to the IP produce. The label evokes credence attributes such as 'sustainably produced' and 'safe food' (Figure 1).

The IP standards for common beans were developed in the 2008/09 winter harvest; however, the norms are still not available for growers until the period of the present research. Consequently, there are no certified beans available for sale in supermarkets. Therefore, the present study was conducted considering the certified beans as a hypothetical product. Indeed, the supply of certified IP products in Brazil is still very low.

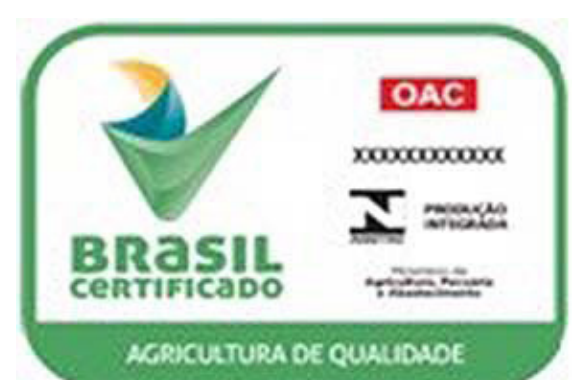

FIGURE 1 - The Brazilian label for IP certification Source: (BRASIL, 2011)

This evidence is verified by the results from prior studies of consumer behavior; most of them were conducted with cases of organic products (Albuquerque Júnior et al., 2013, Hoppe et al., 2012). Some decisive factors that influence the purchase and consumption of organic products on the consumer point of view are health issues, environmental concerns and food safety and taste. Other attributes such as brand, image, certification, traceability and price are not pointed as the most important point in some studies (Hoppe et al., 2012). No published economic research conducted in Brazil was found from the literature review with the focus on consumer behavior towards IP production. Therefore, the present study seeks to contribute with future studies on this issue. 
We focused this study on common beans (Phaseolus vulgaris), specifically the commercial type called 'carioca' beans, because it is one of the staple foods preferred by $76 \%$ of local consumers according to Wander, Basinello, \& Ricardo (2006).

The main objective of this study was to assess the consumer intentions towards purchasing hypothetical IP labeled common beans marketed at a supermarket in Goiania (GO), Brazil. We used the Theory of Planned Behavior (TPB) to attempt the goals of this study. TPB model is one of the most expected value models used in the literature, especially when one wants to explain human behavior in food area. The meta-analysis, proposed by Armitage \& Conner (2001), confirms the efficiency of the TPB model to predict intentions and behaviors in such area.

Besides the results regarding consumer behavior, this study also provides information to stakeholders of supply chain and public administration with basic information on consumer behavior toward IP certified products aiming to establish future strategies to disseminate IP production more efficiently among consumers.

\section{METHODOLOGY}

\subsection{Theory of Planned Behavior}

Over the past 40 years, social psychology theories have gained attention, as it is indicated by the increased use of their applications to predict and understand social behaviors in different domains. One of the most cited authors in this domain is Fishbein and Ajzen (1975).
Initially, these authors proposed the Theory of Reasoned Action (TRA) that assumes that much of human behavior is dependent on human will. Later, an extension of the TRA was proposed with the inclusion of the concept of Perceived Behavioral Control (PBC), representing the confidence of the individual in performing the behavior. According to Ajzen \& Fishbein (1980), PBC influences the intention and even the individual behavior. This new approach was named Theory of Planned Behavior (TPB).

Both TRA and TPB theories suggest that an individual behavior is driven by his/her behavioral intentions to perform the behavior, and these intentions, in turn, depend on other three elements that are considered cognitive structures: a) the combination of attitudes and the influence of behavioral beliefs, $b$ ) the normative beliefs and c) control beliefs (Hattam, 2006). These beliefs are considered indirect influences on behavioral intention. Behavioral intention (BI) itself is mediated through the direct latent factors showed in the TPB model, such as, attitudes (A), subjective norms (SN) and perceived behavioral control (PBC) (Figure 2).

According to Fishbein \& Ajzen (1975), the predictor 'A' represents a person's overall evaluation of the behavior; 'SN' is a person's own estimate of the social pressure to perform or not perform the target behavior, and 'PBC' refers to individuals' perceptions of their ability to perform a given behavior. The theory states that attitudes along with aspects related to the social pressure perceived, available infrastructure and an individual skills are predictors of the behavioral intentions related to a specific behavior. Ajzen (2001) considers that demographic characteristics and prior experience might also be important to the intentions formation.

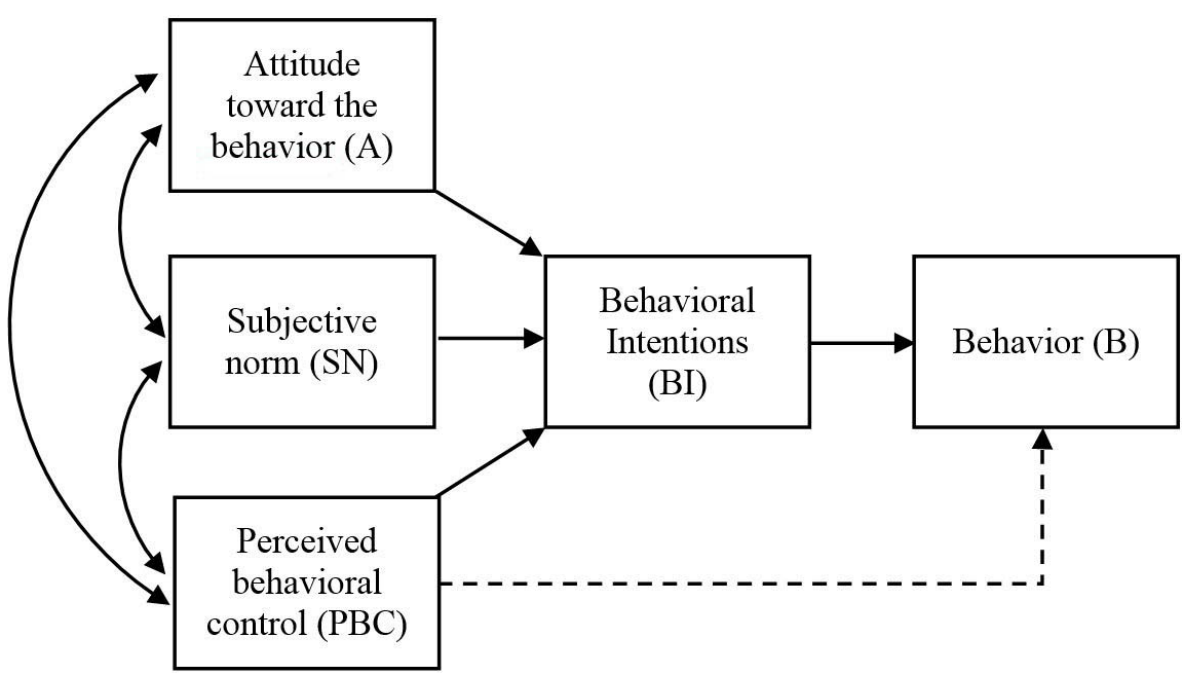

Source: (Fishbein \& Ajzen, 1975)

Organizações Rurais \& Agroindustriais, Lavras, v. 19, n. 3, p. 204-218, 2017 
Although there is not a perfect relationship between BI and $\mathrm{B}$, behavioral intentions can be used as a proxy measure of behavior. Ajzen (2001) states that the intention is the best behavior predictor. Based on this statement, the proposed model aims to verify the consumers' intention to purchase IP certified beans. Intention is the cognitive representation of an individual's readiness to perform a given behavior and it is considered the intermediate behavior antecedent.

This observation is one of the most important contributions of the TPB model compared to previous models of the attitude-behavior relationship. It is expected that the different behaviors and situations faced by an individual change the relative importance of A, SN and the PBC towards the intention prediction (Ajzen \& Fishbein, 1980).

TPB is one of the models most commonly used in research related to human behavior in the food area. There are many studies on consumer behavior of organic products published under the application of the TPB (Kuhar, Slabe, \& Juvančič, 2012; Kuhar \& Juvančič, 2010; Magistris \& Gracia, 2008; Hattam, 2006; Govindasamy \& Italia, 1999; Govindasamy et al., 1998), but few of them focused on IP produce. Hoppe et al. (2012) cite some of these studies developed in Brazil.

Many of these studies reveal that consumer's attitudes towards different organic food attributes such as human health, safety, and the environment are the most important factors that explain the consumer decisionmaking process for organic food products. Positive attitudes towards environmental issues are positively correlated to the buying of such foods (Magistris \& Gracia, 2008). In the present study, we expect similar behavior but towards an IP certified product.

With the exception of $\mathrm{B}$, the variables in the TPB model are psychological (internal) constructs. Each predictor variable is measured directly or indirectly by asking respondents about specific behavioral beliefs and outcome evaluations. This approach makes different assumptions about the underlying cognitive structures and neither approach is perfect. In the present case, we decided to use the indirect measurement according to East (2009).

Overall, the motivation to purchase IP certified agro-food is almost the same of purchasing organic products. Although the concepts of production are different, both IP and organic productions are credence goods. Therefore, one can suppose that the more favorable health and environmental attitudes consumers have, the more likely they will buy IP agro-food products.

Therefore, this study counts with three hypotheses: $\left(\mathrm{H}_{1}\right)$ attitude has a direct effect on intention to purchase
IP certified beans; $\left(\mathrm{H}_{2}\right)$ subjective norms have a direct effect on the intention to purchase IP certified beans; and, $\left(\mathrm{H}_{3}\right)$ perceived behavioral control has a direct effect on intention to purchase IP certified beans. In other words, TPB suggests that the more positive the A, SN and PBC is, the greater the likelihood an individual has of intending to carry out the behavior when the opportunity arises.

\section{DATA COLLECTION AND SURVEY PROCEDURES}

The consumers decision making process can be understood as a social phenomenon constructed from a reality made of perception, belief, attitude, motivation and social behavior. The comprehension of the interaction of all these elements depends on the understanding of the interactions among individuals. It also depends on the understanding of the interactions among them and tangible and intangible aspects that constitute the system of what is intended to investigate (Troilo \& Molteni, 2003).

Data were collected in two stages during 2013 and 2014, comprising a qualitative and a quantitative research, as stated by Troilo \& Molteni (2003). The authors indicate qualitative procedures to identify the consumer salient beliefs. The qualitative research was applied in Nov/2013, when 50 semi-structured interviews were administered to consumers of beans in a supermarket in Goiania (GO), Brazil. The sample size was defined according to East (2009). After applying a content analysis, the results of the interviews were used to elicit salient beliefs models, such as the most important shared beliefs about IP production found in the target sample, which was then included in the quantitative instrument.

The quantitative research involved 160 consumers of beans from a hypermarket also located in Goiania (GO), Brazil. This data was used for hypothesis tests. Most of consumers from Goiania prefer purchasing dry beans in this type of store (Wander et al., 2006; Wander et al., 2007). A previous pilot survey was administered to 24 consumers of beans in order to adjust the main aspects of the survey (Stopher, 2012).

Two diagnostic measures were used to assess the internal consistency on the dataset. One relates to each item separately, including the item-to-total correlation and the inter-item correlation. In this case, the parameter exceeds 0.50 in the item-to-total correlations and 0.30 in the interitem correlations. The second diagnostic measure is related to the entire scale. In this case, the consistency of the entire scale was verified by the reliability coefficient with Cronbach's Alpha; values of 0.60 to 0.70 deemed the lower limit of acceptability (Hair et al., 2006). Both the pilot 
and the final questionnaires were designed considering its validation and reliability according to Hair et al. (2006).

The final version of the questionnaire was constructed considering aspects such as buying behavior and consumption habits, TPB elements, and socio demographic data and was administered face-to-face by trained interviewers. The duration of each interview was about $15 \mathrm{~min}$ and was done in Portuguese language. Two screening questions were done before starting the interview to ensure the respondents were at least 18 years old, and also regular consumers of beans.

Afterwards, the interviewers started the process using a 'cheap-talk' script in order to remove hypothetical bias for relatively ignorant consumers for a good evaluation (Lusk, 2003). The 'cheap-talk' objectives were to explain consumers about the meaning of IP label, evidencing the mainly credence attributes such as 'produced by sustainable practices' and 'free of pesticides residues', and to explain consumers that they would indicate their responses like them would if they were actually facing that options in the hypermarket, considering the hypothetical character of the product.

A convenience sample was chosen due to budget and time constraints, even though it was considered the Hair Jr. et al (2006) orientation to determine the sample size when one intends to use the technique of Structural Equation Modeling (SEM).

\section{STATISTICAL PROCEDURES}

The Confirmatory Factor Analysis (CFA), which is a procedure used to test hypotheses about the structure of a data set, was applied to identify the relationship between the factors and the measurement variables. The technique of Structural Equation Modeling (SEM) was applied by using IBMAMOS® (Analysis of Moment Structures), which simultaneously estimates the model, including latent and observed variables, exogenous and endogenous variables, and the paths to these variables (Adrian, Norwood, \& Mask, 2005).

SEM provides the appropriate and most efficient estimation for a series of separate multiple regression equations that are simultaneously estimated. In practice, SEM relates the hypothesized model constructs, also known as latent variables that are concepts that can be represented by observable or measurable variables. It is indirectly measured by examining consistency among multiple measured variables or indicators.

The two basic components that characterize the SEM are the path model that relates independent to dependent variables even when a dependent variable becomes an independent variable in other relationships and the measurement model that enables the analyst to use several variables or indicators for a single independent or dependent variable (Hair et al., 2006). In this technique, some of the key assumptions of standard regression analysis are violated, such as, the endogenous variables, which appear on the right hand side and are correlated with the residuals and the inconsistence of the least squares estimates (Mazzocchi, 2008).

The SEM was analyzed using the software IBM AMOS $₫ 21$. The maximum likelihood estimation (MLE) was applied because it is the most common SEM estimation procedure, more efficient and unbiased for multivariate normality assumption. The implied null hypothesis of SEM is that the observed sample and SEM estimated covariance matrices are equal, which means that the model fits perfectly. Several statistical tests were used to determine the measurement model and the specific evidence of construct validity by using goodness-of-fit (GOF) rates.

\section{RESULTS AND DISCUSSION}

\subsection{Consumers Characteristics and Consumption Habits}

Descriptive statistics analysis was applied to describe the characteristics of the respondents in terms of socio-demographic profiles. The results indicate that $63 \%$ of the respondents are female. This result converges to that reported by Wander, Basinello \& Ricardo (2006), in which the profile of rice and beans consumers from the Metropolitan Region of Goiania was described. According to Blessa (2003), females are the most ftrequent hypermarkets and supermarkets consumers in Brazil.

The mode of age is between 56-65 years old (35\%), while the average age is ranges from 36-50 years old, representing $25.6 \%$ of the respondents. Basically, this is the same range (between 36-45 years old) reported by Wander, Basinello \& Ricardo (2006) and Wander et al. (2007) in their studies in the same place.

The majority of the respondents are married $(71.3 \%)$ with family size up to 5 people $(86.9 \%)$, and $65 \%$ reported having up to 12 -year-old children at home. Wander, Basinello \& Ricardo (2006) reported family size between $3-5$ people and $80.1 \%$ of their sample had at least one child up to 16 years old. According to Moura, Silva \& Batalha (2006), who characterized the profile of retail consumers from Goiania (among other cities), the number of household people has been diminishing. This evidence can influence their habits of consumption in several ways such as lower predisposition to hold monthly food shopping in large supermarkets, and greater openness to 
higher value-added and convenient foods. The authors also mention that households with 2-5 people prefer to make their purchases in hyper/supermarkets.

In terms of level of education, the largest group is illustrated by the mode that represents the group of people who reported to have finished high school (36.3\%), followed by the elementary school group $(33,8 \%)$. Similarly, from the findings of Wander, Basinello \& Ricardo (2006), the same two groups were the most frequent.

Employed people are also the majority (46.25\%), followed by the retired group (18.75\%) and household workers (14.38\%). Two important groups in terms of acquisition power included autonomous and professional workers (represented by doctors, dentists, lawyers, etc.), representing $15.62 \%$. Students (up to 18 years old) were $3.125 \%$ and $1.37 \%$ were considered unemployed people.

It is possible to comprehend several things about the data on household income such as the fact that the largest group is the one with 3-6 salaries that is equivalent to social classes 'B2' and ' $\mathrm{C}$ ' according to the Brazilian Research Company Association mentioned by Moura, Silva \& Batalha (2006). As observed, 23.1\% of respondents did not report their income. When the non-reported income was excluded from the statistical analysis, the results did not change and the median kept in the same interval of 6-8 salaries. The most frequent household income reported by Wander, Basinello \& Ricardo (2006) was 3-5 salaries (29.2\%), followed by a group with 5-10 salaries (23.7\%). The higher the consumer income is, the most important safety food attribute is considered, which is related to the higher levels of education and access to information of this category (Lima-Filho, Alves, QuevedoSilva, Kondo, Arakak, \& Higashi, 2013).
Regarding the purchasing and consumption habits, $83 \%$ of the respondents self-declared as being the responsible for household food shopping. Beans are purchased almost once a month $(54 \%)$ or twice a month (26\%), in hypermarkets (54\%) and supermarkets (39\%).

Farmers market, neighborhood markets, grocery shops and others represent $7 \%$ of the preferred stores to purchase common beans. Our findings are very similar to that reported by other studies on beans consumer habits in the same municipality. In terms of beans consumption, $91 \%$ of the respondents reported daily beans consumption; this result confirms the importance of dry beans in the Brazilian diet.

We have also questioned consumers if they trust in all beans label information. Approximately 57\% does not trust completely on that and only $43 \%$ of them believe that the information on the labels is reliable. This result indicates that the inclusion of more information on package, such as 'IP label', needs to be included carefully and followed by a good communication towards consumers.

The evaluation of the respondents regarding beans quality attributes is illustrated in Figure 3.

Almost eight out of 10 consumers $(75 \%)$ consider price and brand as the most important attributes to be evident on the beans package, followed by expiration data. Those results are in accordance to other authors that highlight the importance that consumers from Goiania give to the beans brand.

Certification labels, origin, nutritional information and cooking tips were the attributes with less importance to the group of consumers interviewed. Besides that, the attribute certification of quality figures as the fifth most important. This level of importance has to be carefully

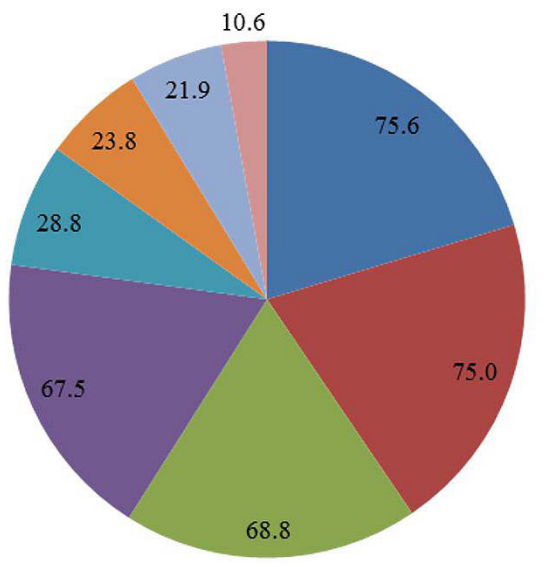

\author{
- Price \\ Brand \\ Best Before \\ - Group/Class/Type \\ n Certification's label \\ Origin \\ Nutritional information \\ Cook tips
}

FIGURE 3 - Beans quality attributes: the importance level reported by respondents Source: Author's elaboration 
interpreted. The relative importance could be justified by the fact that IP label is a new sign of quality for consumers and represents the desire and necessity of the consumers.

On the other hand, the label was the focus of the research and consumers could be over valuating it. LimaFilho et al., (2013) mentioned that food safety is the most relevant factor to Brazilian supermarket consumers. The presence of the quality label had less relevance as well as the nutritional information.

Finally, the consumers were asked about additional information they would consider important and what aspects they would like to see on beans packages regarding some credence attributes related to sustainability and health concerns. The results are shown in Figure 4.

Almost $80 \%$ of the respondents considered important the inclusion of information about environmental responsibility, pesticides residues and health benefits of beans on the packages, while $78.8 \%$ considered important the inclusion of information concerning the type of system of production, for instance, IP system. Information about

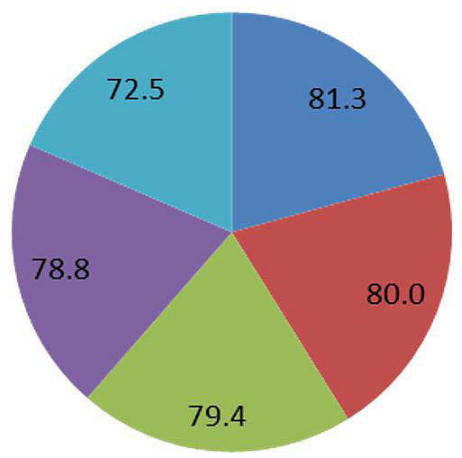

social responsibility appears in the last position but not less important. Local consumers might not be yet familiarized with this kind of quality attributes, i.e., credence attributes. This type of information is more important to bean chain operators aiming at raising consumer awareness for those quality attributes. This positive reaction could be explained by the effect of the novelty.

\subsection{Consumer Intentions Toward Purchasing IP Certified Beans}

Overall, the consumer behavior intention towards purchasing IP certified beans is positive. In the proposed model, the intention to purchase IP certified beans was measured by three variables as it is illustrated in Figure 5 . In a scale from 1 to 7 , consumers reported their level of agreement with this statement, in which 6 indicates a very likely intention towards the proposed action. Attitude towards behavior was measured by three observed variables related to general consumer concerns on personal level of satisfaction and personal health (Figure 6).

FIGURE 4 - Additional label information considered important by the respondents Source: Author's elaboration

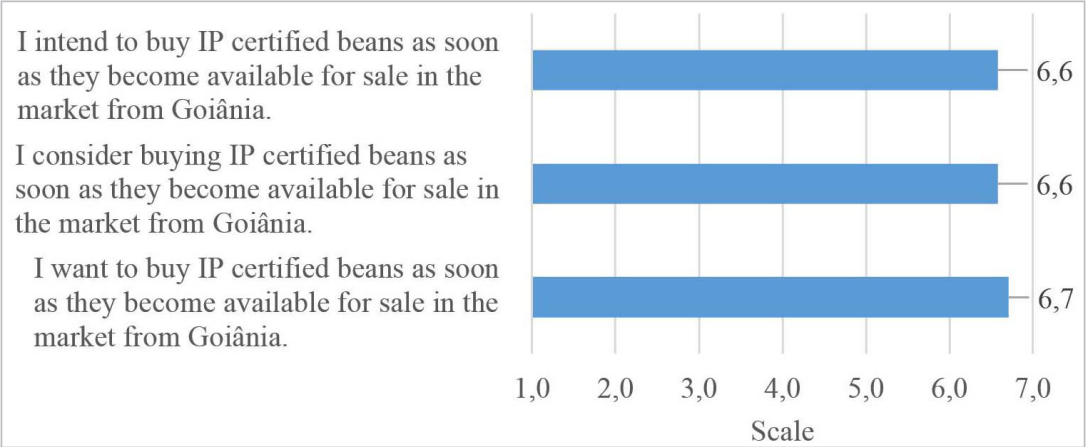

FIGURE 5 - Means of Intention

Source: Author's elaboration

Organizações Rurais \& Agroindustriais, Lavras, v. 19, n. 3, p. 204-218, 2017 
Respondents were asked to rate these sentences on the same scale from 1 to 7 in which 6 means the higher level of agreement. The results demonstrate that consumers have a very likely attitude towards the behavior of purchasing certified beans. This result indicates that consumers have positive feelings about performing the behavior.

The social pressure, measured by the subjective norms, are also important in the context of assuming the behavior of purchasing IP certified beans. There are three different variables used to measure this construct (Figure 7). From a scale from 1 to 7 , six was the highest level of agreement, meaning that people that are important to the respondent think he/she should purchase IP certified beans.

Finally, Figure 8 shows the three variables used to measure the perceived behavioral control. This measure indicates the extent to which the respondents feel able to enact the behavior of purchasing IP certified beans. Similarly, six indicates a high level of agreement of the consumers related to the used variables. Although consumers consider important the opinion of people that are important to them, the choice of purchasing IP certified beans seems not to depend on others. Clearly and reliable information about certified beans is also very important for the consumers to feel confident in performing the behavior.

\subsection{Measurements of Constructs: Testing the Structural Model}

To analyze the factors that affect the intention to purchase IP certified beans, a SEM approach was applied to examine the general fit of the proposed model and to test the hypothesis. A confirmatory factor analysis was applied to assess the measurement model and the SEM analysis to examine the overall relationships among the constructs.

The adequacy of the measurement model was evaluated by the criteria of overall fit with the data, the reliability of each of the constructs evaluated by the ' $\alpha$ ' coefficient and the indicator loadings statistical significance.

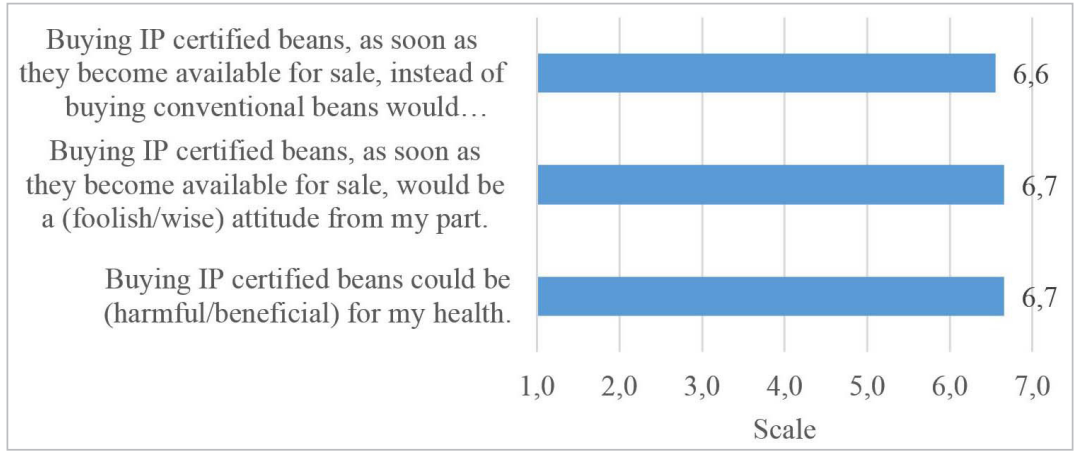

FIGURE 6 - Means of attitudes toward buying certified beans Source: Author's elaboration

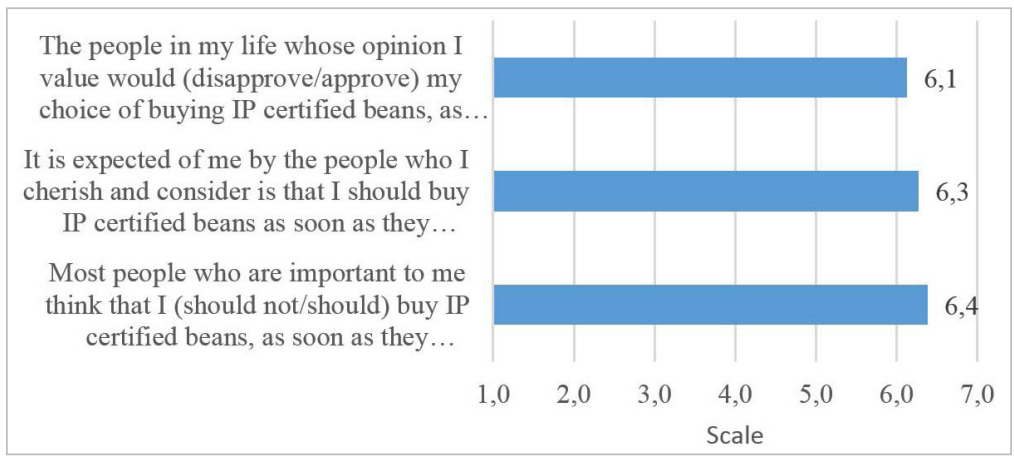

FIGURE 7 - Means of subjective norms

Source: Author's elaboration 


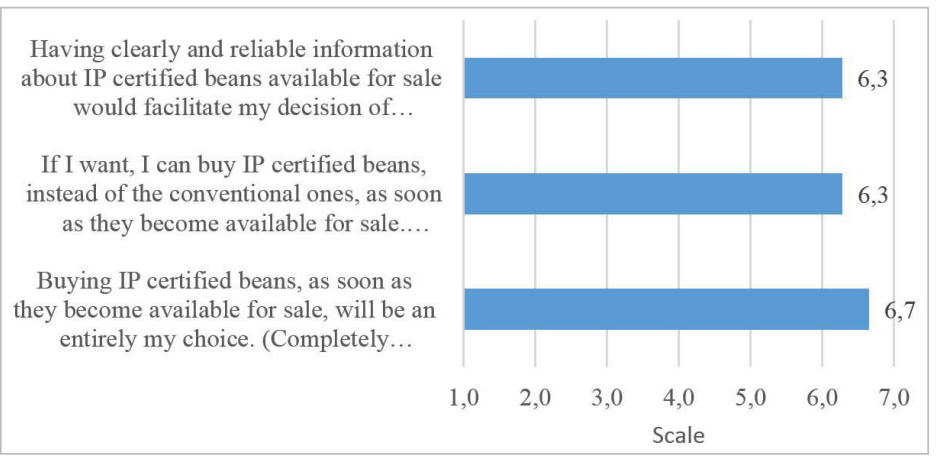

FIGURE 8 - Means of perceived behavioral control

Source: Author's elaboration

The analysis began with a general specification to which explanatory variables were dropped or added in an attempt to increase the number of significant variables and the goodness of the fitting. Since the number of items in the original proposed model was reduced, most of the explanatory variables were remained even if it was not significant. The consistency of the measurement was evaluated by the reliability test. Table 1 indicates the results for the measurement model.

The results indicate that only the ' $\alpha$ ' value of the measuring scale PBC did not achieve the recommended level of $0.60-0.70$. All factor loadings are greater than 0.5 , indicating that the fit of the measurement model is quite reasonable. Furthermore, composite reliabilities (CR) suggest adequate reliability for all the parameters except PBC (smaller than 0.7). By using the AVE measure, the same construct PBC indicates some problems in terms of construct validity since its value is smaller than the baseline equal 0.5 .

Overall, the model fit and measurement model fit assessments were considered in the model fit examination. The recommendation is using three to four fit rates and at least one incremental and one absolute index in addition to the $\chi 2$ value and the associated degrees of freedom. Commonly, a model reporting the $\chi 2$ value and the degrees of freedom, along with the CFI and the RMSEA will often provide sufficient unique information to evaluate a model (Hair, Jr., et al., 2006). The degrees of freedom are a measure of the discrepancy between the available number of observations and the constraints associated with the estimation of unknown parameters. The positive df value (29) indicates that the model is over-identified, for example, there are more elements in the covariance matrix than parameters to be estimated. In this case, estimates are possible but might be neither unique nor optimal. Table 2 shows the model fit summary.
The Chi-square statistic (80.563) is high and significant $(\mathrm{p}$-value $=0.000)$. Considering that the implied null hypothesis of SEM is that the observed sample and SEM estimated covariance matrices are equal, these results are in the correct direction. However, additional rates must be verified to support this general impression of the goodness of the fitting since the Chi-square is sample size sensitive. In the present study, the number of observations and items were reduced and this limitation has reflected on the results. Thus, it is not possible to affirm that there is no discrepancy between the observed covariance matrix and the estimated one. As an alternative, it was used the ratio between the $\chi 2$ value and degree of freedom, indicated by $\mathrm{CDMIN} / \mathrm{df}$, that resulted an acceptable value.

The majority of these fitting indexes resulted in a satisfactory fit between the proposed model and the data, with the exception of the root mean square error of approximation (RMSEA), which should be less than 0.08 . The RMSEA, in turn, indicates the discrepancy between the hypothesized model and the population covariance matrix, and it is more used to avoid problems of large sample size or large number of variables.

The goodness fit index (GFI) measures the goodness of a fit between the hypothesized model and the observed covariance matrix. The comparative fit index (CFI) is derived from the normed fit index (NFI), which indicates the discrepancy between the data and the hypothesized model. Both GFI and CFI were early attempts to produce a statistical fitting that was less sensitive to sample size.

Moreover, the standardized residual covariance matrix can be used in an ultimate analysis. According to (Byrne, 2001), values less than 2.58 suggest a good consistency between the hypothetical and the data. There is no value greater than 2.58, as shown in Table 3 . 
TABLE 1 - Results from the measurement model

\begin{tabular}{|c|c|c|c|c|c|}
\hline \multirow[b]{2}{*}{ Cod. } & \multirow{2}{*}{$\begin{array}{c}(\mathrm{N}=160 ; \mathrm{N} . \text { of Items }=12) \\
\text { Variables }\end{array}$} & \multicolumn{2}{|c|}{$\begin{array}{c}\text { Descriptive } \\
\text { Statistics }\end{array}$} & \multicolumn{2}{|c|}{ Reliability Statistics } \\
\hline & & Mean & $\begin{array}{l}\text { Std. } \\
\text { Dev. }\end{array}$ & $\begin{array}{c}\text { Standardized } \\
\text { factor loading }(\mathrm{g})\end{array}$ & $\begin{array}{l}\text { Cronbach's Alpha } \\
\text { Based on Std. Items }\end{array}$ \\
\hline & Attitude $(\mathrm{A}) / \mathrm{CR}=0.74 / \mathrm{AVE}=0.58$ & & & & $\alpha=0.679$ \\
\hline (A.4) & $\begin{array}{l}\text { Buying IP certified beans as soon as they become available for } \\
\text { sale would be a (foolish/wise) attitude from my part. }\end{array}$ & 6.7 & .7934 & .787 & \\
\hline (A.6) & $\begin{array}{l}\text { Buying IP certified beans as soon as they become available for } \\
\text { sale instead of buying conventional beans would make me feel } \\
\text { more (unsatisfied/satisfied). }\end{array}$ & 6.6 & 1.0687 & .738 & \\
\hline & Subjective Norm $(\mathrm{SN}) / \mathrm{CR}=0.82 / \mathrm{AVE}=0.69$ & & & & $\alpha=0.85$ \\
\hline (NS.2) & $\begin{array}{l}\text { People who I care and consider the most expect me to buy } \\
\text { IP certified beans as soon as they become available for sale. } \\
\text { (Extremely unlikely/Extremely likely). }\end{array}$ & 6.3 & 1.1435 & .854 & \\
\hline \multirow[t]{2}{*}{ (NS.3) } & $\begin{array}{l}\text { People in my life whose opinion I value would (disapprove/ } \\
\text { approve) my choice of buying IP certified beans as soon as } \\
\text { they become available for sale. }\end{array}$ & 6.1 & .8477 & .807 & \\
\hline & Perceived Behavioral Control $(\mathrm{PBC}) / \mathrm{CR}=0.59 / \mathrm{AVE}=0.33$ & & & & $\alpha=0.593$ \\
\hline (CP.3) & $\begin{array}{c}\text { Having clearly and reliable information about IP certified } \\
\text { beans available for sale would facilitate my decision of } \\
\text { purchasing. (Completely disagree/Completely agree). }\end{array}$ & 6.3 & .7519 & .584 & \\
\hline (CP.6) & $\begin{array}{l}\text { Buying IP certified beans as soon as they become available } \\
\text { for sale would be entirely my choice. (Completely disagree/ } \\
\text { Completely agree). }\end{array}$ & 6.7 & .7786 & .570 & \\
\hline \multirow[t]{2}{*}{ (CP.5) } & $\begin{array}{l}\text { If I want, I can buy IP certified beans instead of the } \\
\text { conventional ones, as soon as they become available for sale. } \\
\text { (Extremely unlikely/Extremely likely) }\end{array}$ & 6.3 & 1.1825 & .564 & \\
\hline & Intention $(\mathrm{I}) / \mathrm{CR}=0.89 / \mathrm{AVE}=0.74$ & & & & $\alpha=0.893$ \\
\hline (I.1) & $\begin{array}{l}\text { I consider buying IP certified beans as soon as they become } \\
\text { available for sale in the market of Goiania. }\end{array}$ & 6.6 & .9935 & .862 & \\
\hline (I.2) & $\begin{array}{c}\text { I want to buy IP certified beans as soon as they become } \\
\text { available for sale in the market of Goiania. }\end{array}$ & 6.7 & .8437 & .864 & \\
\hline (I.3) & $\begin{array}{c}\text { I intend to buy IP certified beans as soon as they become } \\
\text { available for sale in the market of Goiania. }\end{array}$ & 6.6 & 1.0369 & .846 & \\
\hline
\end{tabular}

Source: Author's elaboration

TABLE 2 - Model fit summary

\begin{tabular}{ccc}
\hline Measures & Estimated Model & Acceptable values \\
\hline$\chi^{2}$ & 80.563 & $\downarrow$ value \\
df & 29 & $\uparrow * *$ value \\
p-value & .000 & $\geq .90$ \\
GFI & .908 & $\geq .90$ \\
CFI & .934 & $<.08$ \\
RMSEA & .106 & $1-5$ \\
CDMIN/df & 2.778 & \\
\hline
\end{tabular}

Source: Author's elaboration 
The final model comprised a total of 25 variables, with 10 observed variables, 15 unobserved variables, 14 exogenous, and 11 endogenous variables. The results of SEM Analysis (standardized) are illustrated in Tables 4 and 5. Standardized structural coefficient estimates were used to compare the relative importance of the independent variables.

Table 4 and Figure 9 show the structural model, the hypothesis tests results and SEM analysis.

As shown in Table 4, considering the factors that influence the purchase intention of IP certified beans, significant path was found only for the attitudes. The positive coefficient indicates a direct relation between attitude and behavioral intention; the more favorable the attitude is, the greater the intention of buying IP certified beans by consumers. In other words, this result reinforces the importance of the variable attitude to explain the intention to purchase, as conceived by the TPB model.

Moreover, as in this research the attitudes were positive and resulted in high means, it can be said that such consumers of certified beans have very favorable attitudes towards these products and that their beliefs strongly influence their choices. The subjective norms and PBC had no significant effect on intention of purchasing IP certified beans.

TABLE 3 - Standardized residual covariance matrix

\begin{tabular}{c|cccccccccc}
\hline & CP.3 & CP.5 & CP.6 & I.3 & I.2 & I.1 & NS.2 & NS.3 & A.6 & A.4 \\
\hline CP.3 & .000 & & & & & & & & & \\
CP.5 & -.081 & .000 & & & & & & & & \\
CP.6 & .564 & -.521 & .000 & & & & & & & \\
I.3 & -.336 & 1.595 & -1.199 & .000 & & & & & & \\
I.2 & -.401 & .999 & -.243 & -.102 & .000 & & & & & \\
I.1 & -.660 & 1.560 & -1.158 & .274 & -.149 & .000 & & & & \\
NS.2 & .576 & -.412 & -.125 & -.771 & 1.035 & -.227 & .000 & & & \\
NS.3 & .701 & .501 & -1.331 & -.853 & .373 & .183 & .000 & .000 & & \\
A.6 & -1.186 & -.176 & -1.735 & .112 & .438 & .853 & .087 & .379 & .000 & \\
A.4 & .503 & .211 & 1.717 & -.104 & -.096 & -.887 & -.194 & -.119 & .000 & .000 \\
\hline
\end{tabular}

Source: Author's elaboration

TABLE 4 - Structural Model and Hypothesis testing

\begin{tabular}{ccc|cccc}
\hline & & & Estimate & S.E. & C.R. & P \\
\hline Intention & $<---$ & SN & -.011 & .249 & -.046 & $.963 \mathrm{~ns}$ \\
Intention & $<---$ & ATT & 1.686 & .679 & 2.484 & $.013^{*}$ \\
Intention & $<---$ & PBC & -.729 & .731 & -.997 & $.319 \mathrm{~ns}$ \\
\hline NS.3 & $<---$ & SN & 1.000 & & & \\
NS.2 & $<---$ & SN & 1.428 & .164 & 8.721 & $* *$ \\
CP.3 & $<---$ & PBC & .989 & .201 & 4.911 & $* *$ \\
CP.6 & $<---$ & PBC & 1.000 & & & $*$ \\
CP.5 & $<---$ & PBC & 1.502 & .312 & 4.817 & $*$ \\
A.4 & $<---$ & ATT & 1.000 & & & $*$ \\
A.6 & $<---$ & ATT & 1.263 & .132 & 9.552 & $*$ \\
I.1 & $<---$ & Intention & 1.000 & & & $*$ \\
I.2 & $<---$ & Intention & .851 & .062 & 13.765 & $* *$ \\
I.3 & $<---$ & Intention & 1.025 & .077 & 13.343 & $* *$ \\
\hline
\end{tabular}

$\mathrm{NS} /$ not significant at the 0.05 level; */significant at the 0.05 level; **/ significant at the 0.001 level Source: Author's elaboration

Organizações Rurais \& Agroindustriais, Lavras, v. 19, n. 3, p. 204-218, 2017 


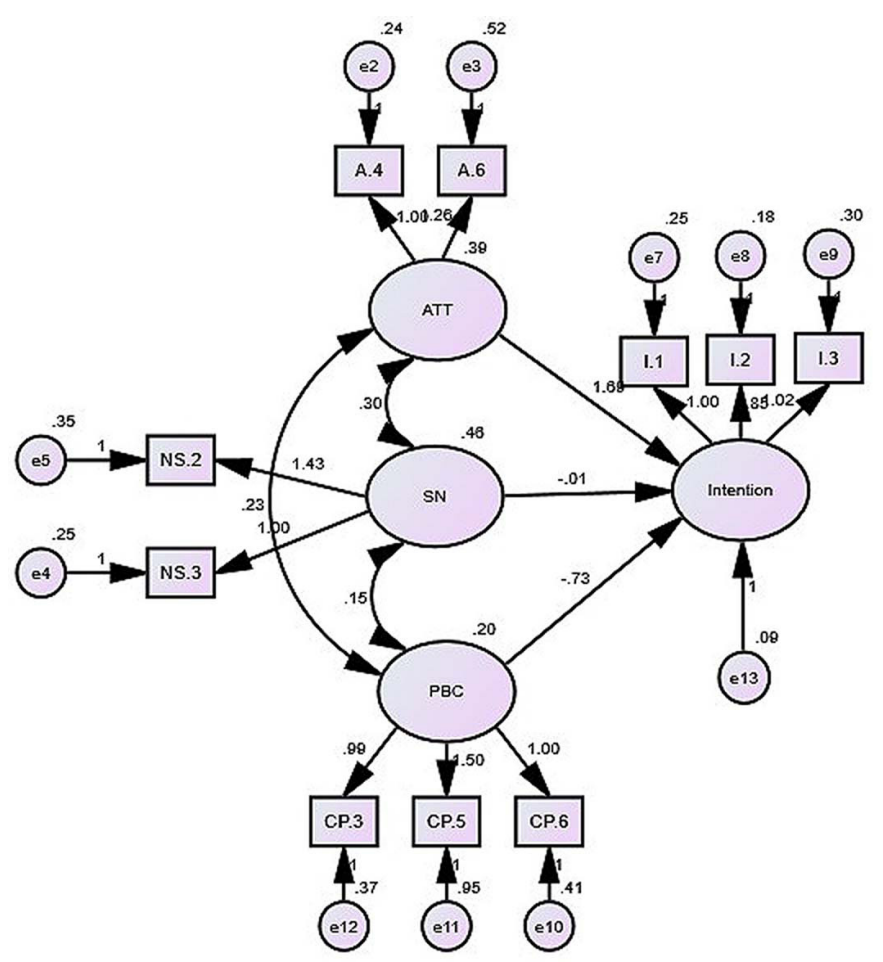

FIGURE 9 - Results of SEM Analysis (standardized)

Source: Author's elaboration

With regard to the subjective norms, the results were similar to those found in other studies in Brazil (Barcellos, 2007). From the interviewed consumers of the present study, 'people they respect and admire' are not significant elements in determining the intention of purchasing certified beans, possibly by the fact that this product is seen as a type of product that brings benefits to health. Additionally, the consumer has control over his own acts of choice and shopping.

\section{CONCLUSIONS AND RECOMMENDATIONS}

The results of this study reveal that the interviewed consumers have a positive attitude towards the purchasing of IP certified beans, even though this product is not currentlyavailable in Brazilian stores. This positive point might be associated to an unmet demand for safe food, free of pesticide residue and produced in a sustainable way.

Additionally, the results suggest that clear and reliable information about the certification label may favor the process of certified beans marketing since the consumer will have an easy access to IP label information. Thus, they will be more confident about what they are buying and consuming. Moreover, this can help the process of expansion of the Brazilian market of certified food products. According to Rocha (2010), mentioned by Hoppe, Barcellos Vieira \& Matos (2012), there is a potential market for this type of product in the big city centers of Brazil

Furthermore, the choice and the decision of purchasing certified beans seem to be directly related to the price that will be practiced in the market. Therefore, the respondents do not feel completely able to perform the action of purchasing certified beans because the action of purchasing will be subject to the prices. If the differential price of the certified beans is greater than the consumer expectations, the consumer probably may alternatively opt for the conventional beans.

The results indicate that the theoretical model based on the TPB used to explain the intention behavior of purchasing certified beans resulted in reasonable fit rates, but it was consistent with the theory with only some of the relations among constructs. Thus, the results showed that the proposed model was adequate for explaining the consumer behavior toward the IP certified beans purchasing. As exceptions, one can refer the constructs subjective norms and perceived behavioral control towards the intention of purchasing. 
However, the application of this research with a higher number of respondents could possibly produce more robust results. It is also necessary to recognize the limitations of any survey instrument when it is applied to different cultural contexts, especially in the case in which the central element is related to psychological issues.

The subjective norms in this study were not significant in the model, which indicates that the opinion of others is not a decision-making factor for the intention of buying certified beans from the point of view of the surveyed consumers. This construct was measured by only two indicators, which may have affected their performance in the modeling.

In any case, this research used a case of a hypothetical product that is not known by the surveyed consumers. This factor may also have influenced the consumer decisionmaking in relation to some issues raised in the model.

The consumer expectation that the certified beans can be sold in the habitual retail stores did not affect the consumer possible behavior of buying certified beans. On the opposite, the price to be charged for this product can positively or negatively influence consumer behavior in relation to the purchase of certified beans.

This study brings important contributions from the application of TPB in the field of certified food products from integrated production in the Brazilian context. It can be said, based on the literature review, that there are few similar studies conducted in Brazil. Therefore, one of the contributions of this work is related to the scientific community that can use the results of this study as a basis for similar future research.

Another contribution of this study is targeted to the various agents of the Brazilian beans supply chain. The results show that there is a great opportunity in the market for those that wish to invest in the market of certified products with sustainable and food-safety claims. The beans growers may benefit from the present results with the information that the consumer has a positive attitude toward certified beans purchase and, therefore, there is a latent demand for this type of product.

On the other hand, the retail stores should be alert to promote the certified products in a clear and reliable way, since these criteria are flagged as important from the point of view of consumers. The consumer must trust the certification label into consideration, as the quality attributes that differentiate the IP certified products are credence attributes and cannot be directly observed by consumers in the available products on supermarket shelves.

It is important to notice that the results of this study are valid only for consumers interviewed in Goiania (GO) and cannot be generalized for Brazil as a whole. So, one cannot infer behaviors and/or attitudes for all Brazilian consumers based on these results.

As recommendations for future research within the same field, we suggest performing similar research in other large Brazilian centers to promote a culture research focused on consumer behavior, which is still very few explored in Brazil. We also suggest the interaction of SDC to TPB model to stratify the results and return a better understanding about the consumer behavior with different profiles. Finally, it is important to emphasize that this type of model must be applied in situations where it is possible to have a sufficient minimum number of respondents in order to avoid problems during the model validation, such as the one faced in this research.

\section{REFERENCES}

ADRIAN, A. M.; NORWOOD, S. H.; MASK, P. L. Producers' perceptions and attitudes toward precision agriculture technologies. Computers and Electronics in Agriculture, New York, v. 48, p. 256-271, 2005.

AJZEN, I. Nature and operation of attitudes. Annual Review of Psychology, Palo Alto, v. 52, p. 27-58, 2001.

AJZEN, I.; FISHBEIN, M. Understanding attitudes and predicting social behavior. Englewood Cliffs: PrenticeHall, 1980.

ALBUQUERQUE JÚNIOR, E. P. et al. Aspectos relativos à saúde e ao meio ambiente ligados ao consumo de alimentos orgânicos. Revista de Administração da UFSM, Santa Maria, v. 6, p. 295-312, maio 2013.

ARMITAGE, C. J.; CONNER, M. Efficacy of the Theory of Planned Behaviour: a meta-analytic review. British Journal of Social Psychology, London, v. 40, p. 471-499, 2001.

BARCELLOS, M. D. Beef lovers: um estudo cross-cultural sobre o comportamento de consumo de carne bovina. 2007. 328 p. Tese (Doutorado em Agronegócios)-Universidade Federal do Rio Grande do Sul, Porto Alegre, 2007.

BIROL, E. et al. Developing country consumers' demand for food safety and quality: is Mumbai ready for certified and organic fruits? In: INTERNATIONAL ASSOCIATION OF AGRICULTURAL ECONOMISTS CONFERENCE, 2009, Beijing. Proceedings... Beijing, 2009. 1 CD-ROM. 
BRASIL. Instrução Normativa $n^{\circ} 27$, de 30 de agosto de 2010. Diretrizes gerais com vistas a fixar preceitos e orientações para os programas e projetos que fomentem e desenvolvam a Produção Integrada Agropecuária (PIBrasil). Diário Oficial da União, Brasília, DF, n. 167, p. 7, 2010. Seção 1.

BRASIL. Portaria no 443, de 23 de novembro de 2011. Requisitos de Avaliação da Conformidade para Produção Integrada Agropecuária. Brasília, DF, 2011. Available at: <http://www.inmetro.gov.br/legislacao/rtac/pdf/ RTAC001761.pdf $>$. Access in: 10 mar. 2016.

BRASIL. Produção integrada da cadeia agrícola. Available at: <http://www.agricultura.gov.br/desenvolvimentosustentavel/producao-integrada $>$. Access in: 19 Apr. 2015.

BYRNE, B. M. Structural equation modeling wity AMOS. Lawrence: Mahwah, 2001.

CASWELL, J. A.; SINY, J. Consumer demand for quality: major determinants for agricultural and food trade in the future? Journal of International Agricultural Trade and Development, Fargo, v. 4, n. 1, p. 99-116, 2007.

EAST, R. Comportamento del consumatore. Milano: Apogeo Education, 2009.

FISHBEIN, M.; AJZEN, I. Belief, attitude, intention, and behavior: an introduction to theory and research. 1975. Available at: <http://people.umass.edu/aizen/f\&a1975. html>. Access in: 15 Apr. 2014.

FONTES, M. A.; GIRAUD-HÉRAUD, E.; PINTO, A. S. Consumers' behaviour towards food safety: a literature review: cahier de recherche 2013-26. Paris: École Polytechnique, 2013.

GOVINDASAMY, R. et al. Consumer response to IPMgrown produce. Journal of Extension, Madison, v. 36, n. 4, Aug. 1998. Available at: <https://www.joe.org/ joe/1998august/rb2.php>. Access in: 15 Apr. 2016.

GOVINDASAMY, R.; ITALIA, J. Identifying the market environment and consumer attitudes facing the introduction of integrated pest management produce. Journal of the ASFMRA, Glendale, v. 4, n. 5, p. 55-62, 1999.

HAIR, J. et al. Multivariate data analysis. Upper Saddle River: Pearson Prentice Hall, 2006.
HATTAM, C. Adopting organic agriculture: an investigation using the Theory of Planned Behaviour. In: INTERNATIONAL ASSOCIATION OF AGRICULTURAL ECONOMICS CONFERENCE, 2006, Gold Coast. Proceedings... Gold Coast, 2006. 1 CD-ROM.

HOPPE, A. et al. Comportamento do consumidor de produtos orgânicos: uma aplicação da teoria do comportamento planejado. Revista de Administração e Contabilidade da UNISINOS, São Leopoldo, v. 9, n. 2, p. 174-188, abr./jun. 2012.

INTERNATIONALORGANISATIONFORBIOLOGICAL INTEGRATED CONTROL. IOBC-WPRS IP \& IPM: integrated production principles of IOBC. Paris, 2004. Available at: <https://www.iobc-wprs.org/ip_ipm/IOBC_ IP_principles.html $>$. Access in: 20 Sept. $201 \overline{5}$.

KUHAR, A.; JUVANČIČ, L. What determines purchasing behaviour for organic and integrated fruits and vegetables? Bulgariam Journal of Agricultural Science, Sofia, v. 16, n. 2, p. 111-122, 2010.

KUHAR, A.; SLABE, A.; JUVANČIČ, L. Determinants of purchasing behaviour for organic and integrated fruits and vegetables: the case of the post socialist economy. In: REED, M. (Ed.). Organic food and agriculture: new trends and developments in the social sciences. Rijeka: Intech Europe, 2012. p. 19-38.

LIMA-FILHO, D. D. et al. Decisão de compra das classes A-B em supermercados. Revista Cesumar Ciências Humanas e Sociais Aplicadas, Maringá, v. 18, n. 2, p. 353374, jul./dez. 2013.

LUSK, J. L. Effects of cheap talk on consumer willingnessto-pay for golden rice. American Journal of Agricultural Economics, Saint Paul, v. 85, n. 4, p. 840-856, Nov. 2003.

MAGISTRIS, T. D.; GRACIA, A. The decision to buy organic food products in Southern Italy. British Food Journal, Bradford, v. 9, p. 929-947, 2008.

MAZZOCCHI, M. Statistics for marketing and consumer research. London: SAGE, 2008.

MOSER, R.; RAFFAELLI, R.; MCFADDEN, D. T. Consumer preferences for fruit and vegetables with credence-based attributes: a review. International Food and Agribusiness Management Review, New York, v. 14, n. 2, p. 121-142, 2011. 
MOURA, T. L.; SILVA, A. L.; BATALHA, M. O. Perfil dos consumidores que frequentam os formatos de varejo de alimentos no Brasil. In: ENCONTRO DAASSOCIAÇÃO NACIONAL DE PÓS-GRADUAÇÃO E PESQUISA EM ADMINISTRAÇÃO, 30., 2006, Salvador. Anais... Salvador: ANPAD, 2006. Available at: $<$ http://www.gepai. dep.ufscar.br/pdfs/1187722982_MKTB2054_thais.pdf>. Access in: 20 May 2015.

SCARPA, R.; SPALATRO, F.; CANAVARI, M. Investigating preferences for environmental friendly production practices: taste segments for organic and integrated crop management in italian households. In: JOINT CONFERENCE ON FOOD, AGRICULTURE AND THE ENVIRONMENT, 8., 2002, Red Cedar Lake. Proceedings... Wisconsin: University of Minnesota, 2002. p. 1-10.
STOPHER, P. Collecting, managing, and assessing data using sample surveys. Cambridge: Cambridge University Press, 2012.

TROILO, G.; MOLTENI, L. Introduzione alla ricerca di marketing. Milano: Mc-Graw-Hill, 2003.

WANDER, A. E.; BASINELLO, P. Z.; RICARDO, T. R. Perfil dos consumidores de arroz e feijão na Região Metropolitana de Goiânia. Santo Antônio de Goiás: EMBRAPA Arroz e Feijão, 2006. (Comunicado Técnico, 127).

WANDER, A. E. et al. Alimentos orgânicos: oportunidades de mercado e desafios. Revista de Política Agrícola, Brasília, DF, ano 16, n. 2, p. 44-55, abr./jun. 2007. 